\title{
A QUALITATIVE STUDY OF GREEN HRM PRACTICES AND THEIR BENEFITS IN THE ORGANIZATION: AN INDONESIAN COMPANY EXPERIENCE
}

\author{
Lieli SUHARTI*, Agus SUGIARTO(D) \\ Fakultas Ekonomika dan Bisnis, Universitas Kristen Satya Wacana, Indonesia
}

Received 22 October 2019; accepted 20 January 2020

\begin{abstract}
Green Human Resource Management (HRM) aims to shape employee behavior to help organizations achieve their environmentally-friendly goals. Firms can translate the implementation of Green HRM concept into each HRM function. This paper is qualitative exploratory research that investigates the implementation of Green HRM in a company located in Indonesia that is internationally reputable for being an environmentally friendly company. This study aims to highlight the implementation of Green HRM through various HRM functions and to analyze the positive impacts of the implementation of Green HRM on individuals and organizations. The results demonstrated that the implementation of Green HRM provided benefits for individual employees and the company as well. In particular, individual employees had better green and non-green work outcomes. Meanwhile, at the organizational level, the benefits of the implementation of Green HRM were the creation of environmentally friendly organizational culture and work climate, the increased efficiency of various resources, the formation of positive corporate image and increased economic and eco-performance. It is expected that this study contributes to extend the literature on the implementation of Green HRM and its benefits to companies.
\end{abstract}

Keywords: Green Business, Green HRM, individual benefits, organizational benefits, corporate sustainability.

JEL Classification: J53, M54, Q56.

\section{Introduction}

Global warming and environmental pollution have become major global concerns that require greater awareness of environmental ethics from all related parties, including companies as the business actors. Companies' efforts to preserve the environment need to be supported by environmentally friendly employees and all members of companies at all levels. Consequently, employees must have higher moral standards and environmentally friendly behavior (Jackson et al., 2011; Bissing-Olson et al., 2013; Devi Kalpana, 2018) or commonly known as a pro-environmental commitment (Luu, 2018). According to the Business Resource Efficiency Guide, environmentally friendly behavior will benefit companies by reducing unnecessary costs, increasing resource efficiency, improving environmental performance, and improving corporate image.

Human resource management (HRM) is one of the strategic organizational functions to manage human resources. Organizations can stimulate the positive behaviors of employees and other organizational members through HRM. It is also believed that HRM facilitates organizations to shape employees' environmentally friendly behavior. The application of the Green Business concept in HRM is also called Green Human Resource Management or Green HRM (Aykan, 2017). Green HRM creates environmentally friendly behavior and culture, both at individual and organizational levels (Cherian \& Jacob, 2012; Opatha \& Arulrajah, 2014; Devi Kalpana, 2018). Specifically, Green HRM aims to create, improve, and maintain environmentally friendly morals for employees so that they can contribute to a healthy environment (Rani \& Mishra, 2014), and eventually, to environmental sustainability (Mehta \& Chugan, 2015). Another discipline that also promotes "green" organizations is Sustainable Human Resource Management (SHRM). SHRM has contributed to developing a sustainable work environment and facilitating the achievement of Sustainable Development Goals (SDGs) (Aguinis \& Glavas, 2012; Pfeffer, 2010; Chams \& García-Blandón, 2019).

Many countries currently implement Green HRM as a strategy to create sustainable competitive advantage

${ }^{*}$ Corresponding author. E-mail: lieli.suharti@uksw.edu 
(Aykan, 2017; Leonidou et al., 2017) through good organizational environmental performance (Rawashdeh, 2018). It can even also enhance the efficiency of companies' use of resources and their environmental sustainability (Shaikh, 2010; Ragas et al., 2017). Although numerous scholars have proposed the positive impacts of Green HRM on companies, as a relatively new field of research, only a few studies have demonstrated the positive effects at both the individual and organizational levels. Additionally, the literature on Green HRM is mostly theoretical and focuses on the perspectives of western countries. For example, based on the review of the antecedents and outcomes of SHRM, Chams and García-Blandón (2019) showed the obstacles to sustainable implementation not only at the company level but also from an international perspective. Although in recent years several studies have emerged from Asian countries, the numbers are still relatively limited. Meanwhile, several scholars also recommended empirical crosscountry studies on companies' environmentally friendly behavior (Jackson et al., 2011; Alhadid \& Abu-Rumman, 2014; Rani \& Mishra, 2014).

In this respect, Indonesia is facing serious environmental problems. Based on the Environmental Performance Index (EPI) ranks of countries' performance on high-priority environmental issues, Indonesia's environmental quality in 2016 was on the $107^{\text {th }}$ out of 180 countries with a score of 65.85 . In addition to Indonesia's low rank in EPI 2016 internationally, the Ministry of Energy and Mineral Resources of the Republic of Indonesia stated that $80 \%$ of total energy waste was caused by human factors. Although Indonesia has relatively sufficient instruments (regulations) to control the environment, environmental problems tend to escalate. Understandably, to overcome environmental problems, the government asks companies to enhance their awareness to apply the Green Business and Green HRM concepts to create a green attitude and behavior among their employees. Based on these arguments, this study asks how companies in Indonesia implement Green Business and Green HRM.

This study is qualitative research in an internationally reputable company in Indonesia that has applied the Green Business and sustainable HRM concept. It was a multinational cement company. People often associate the cement industry with environmental damages. To demonstrate that this industry did not always damage the environment, the company had applied the Green Business concept since 2000. As a result, the company received various awards, such as the Green Company Awards (2013), Eco-Friendly Company certification (2015), Eco-Office certificates based on the Singapore Environmental Council criteria (2015), PROPER gold medal from the Indonesian Ministry of Environment (six times), Sustainable Business Awards: Best Strategy \& Sustainability (2017), Social Business Innovation \& Green CEO award (2017), and Indonesia Green Companies award (2018).

Based on the background and the company's performance, the study selected the company as the research object. Thus, this study aims to highlight: 1) how the studied company implemented the Green Business concept in the form of Green HRM through the policies and practices of various HRM functions; and 2) the positive impacts of the implementation of Green HRM on individuals and organizations. It is expected that this study contributes by underscoring the benefits of the implementation of Green HRM for companies.

\section{Literature review}

\subsection{Green HRM and its implementation}

Environmentally friendly behavior is defined as behavior that does not damage and therefore, does not bring negative impacts on the surrounding natural environment. In this respect, a Green Business concept emerges that refers to companies that are committed to preserving environmental sustainability in their operations, striving to use renewable resources, and trying to minimize the negative impacts of their activities on the environment (Čekanavičius, Bazytė, \& Dičmonaitè, 2014).

The literature suggested that companies could implement the Green Business concept through the implementation of Green HRM (Jackson et al., 2011; Opatha \& Arulrajah, 2014; Nejati, Rabiei, \& Chiappetta Jabbour, 2017; Yong et al., 2019) because human resources had an important role in building organizational culture, including an environmentally friendly one. According to Paillé et al. (2014), HRM is closely related to organizations' environmental concerns and eventually to organizations' environmental performance. Additionally, Cherian and Jacob (2012) also revealed that companies needed to implement Green HRM to improve their employees' morale towards good environmental management.

Green HRM is the application of HRM that aims to motivate employees' behavior to help organizations achieve their environmentally-friendly goals and contribute to environmental sustainability by showing environmentally friendly behavior. Green HRM includes policies, practices, and systems that encourage employees to behave environmentally friendly for the benefits of individuals, the society, natural environment and business (Opatha \& Arulrajah, 2014; Jackson et al., 2011; Nejati, Rabiei, \& Jabbour, 2017; Yog et al., 2019). In a similar vein, Mehta and Chugan (2015), Jabbour and de Sousa Jabbour (2016) also argued that Green HRM relied on every potential employee to promote sustainable practices and to increase employee awareness and commitment to environmental issues in a sustainable manner.

Companies can translate the implementation of the Green HRM concept into each HRM function which generally includes the functions of recruitment and selection, employee training and development, performance management, reward and punishment, and employee empowerment functions (Opatha \& Arulrajah, 2014). Also, Siyambalapitiya, Zhang, and Liu (2018) there has been renewed interest in green transformation; however, research 
on green human resource management (GHRM stated that research on Green HRM had significantly focused on conceptual clarification and refinement. Further, while the literature has produced many theoretical achievements, it has produced little empirical evidence. Thus, companies can integrate their HRM practices into environmental management activities to improve environmental performance instead of inappropriately fitting employees into environmental management systems to achieve environmental objectives. For example, for the recruitment and selection function, companies can implement Green HRM by incorporating environmental criteria into recruitment and selection content. In this respect, companies need to communicate their environmental concerns to prospective workers in the recruitment process (Opatha \& Arulrajah, 2014).

In the training and development function, Renwick, Redman, and Maguire (2013) argued that employee training in environmental management aimed to increase employees' awareness, skills, and expertise on environmental issues. For example, companies can provide appropriate knowledge and skills on environmentally friendly behavior to their employees through training programs that were specifically designed for this issue. Opatha and Arulrajah (2014) argued that it was important to include environmentally friendly values during the orientation period to familiarize new employees with organizations' environmentally friendly activities.

The performance management system complements Green HRM practices by developing environmental performance standards and indicators. For example, companies can link their performance evaluation with their environmentally-friendly goals and explicitly specify the goals and tasks in the job description (Renwick, Redman, \& Maguire, 2013; Mehta \& Chugan, 2015). Specifically, companies need to communicate their environmentallyfriendly schemes to all levels of staff through a performance appraisal scheme. Also, it is necessary to set targets for managers/employees to be environmentally friendly (Opatha \& Arulrajah, 2014).

In terms of the reward and punishment functions, Phillips (2007) emphasized that incentives and rewards could influence employees' attention to the potentials in their workplaces and to motivate them to exert optimal efforts to help achieve organizational goals. In the context of Green HRM, rewards and compensation potentially support environmentally friendly activities in organizations (Renwick, Redman, \& Maguire 2013; Opatha \& Arulrajah, 2014; Macke \& Genari, 2018; Haridas \& Sivasubramanaian, 2016; Siyambalapitiya, Zhang, \& Liu, 2018; Sayyadi Tooranloo, Azadi, \& Sayyahpoor, 2017; Wu et al., 2019). Consequently, companies need to formulate and publish rules related to environmentally friendly behavior. Besides, in accordance with a strategic approach to compensation management, organizations can develop a reward system to encourage employees to propose environmentally friendly initiatives.

\subsection{The benefits of Green HRM for organizations}

The application of environmentally friendly concepts in organizations likely provided benefits or positive impacts on companies. Several studies suggest that the application of Green HRM had a positive impact on employee, organizational, and environmental performance. Specifically, the application of Green HRM improved environmental management systems such as efficient use of resources (Florida \& Davison, 2001) and reduced waste and pollution from the workplace (Kitazawa \& Sarkis, 2000; Phillips, 2007).

At the organizational level, the implementation of Green HRM enhanced resource efficiency and economic impact (Alhadid \& Abu-Rumman, 2014), improved organizational performance (Renwick, Redman, \& Maguire, 2013; Gotschol, De Giovanni, \& Vinzi, 2014; Wu et al., 2019), created stronger public image and brand recognition (Cherian \& Jacob, 2012; Haridas \& Sivasubramanaian, 2016), reduced companies' environmental impact and creates sustainable competitive advantages (Aykan, 2017; Leonidou et al., 2017; Siyambalapitiya, Zhang, \& Liu 2018; Macke \& Genari, 2018; Sayyadi Tooranloo, Azadi, \& Sayyahpoor, 2017), and improved organizational and environmental performance (Cherian \& Jacob, 2012; Ragas et al., 2017; Siyambalapitiya, Zhang, \& Liu, 2018; Macke \& Genari, 2018; Wu et al. 2019). Several other studies such as Mehta and Chugan (2015), Rawashdeh (2018), Obaid and Rosima (2015), Sayyadi Tooranloo, Azadi, and Sayyahpoor (2017) found that corporate practices that were based on pro-environment have a positive impact on sustainable environment and organizational performance.

Several studies demonstrated that companies that implemented a greater level of environmental management system enjoyed greater benefits from it and improved their environmental performance (Wagner, 2013; Wu et al., 2019). Meanwhile, companies that consistently held the "reduce and reuse" principle when implementing environmentally friendly concepts managed to save costs, especially those related to electricity and water (Ekasatya, 2014). The finding is in line with Haridas and Sivasubramanaian (2016) who showed the cost-cutting benefits of the application of Green HRM.

At the individual level (employees), the application of Green HRM increased individual empowerment that eventually enhanced productivity and performance and facilitated self-control and problem-solving skills (Soo Wee \& Quazi 2005; Renwick, Redman, \& Maguire 2013). Also, Cherian and Jacob (2012) added that the application of Green HRM could improve employee involvement, made employees feel more comfortable in companies, and attract high-quality employees to join the company. Additionally, it increased employee moral (Renwick, Redman, \& Maguire, 2013; Gotschol, De Giovanni, \& Vinzi, 2014), and produced psychological green climate (Dumont, Shen, \& Deng, 2017) and environmentally friendly workplace (Haridas \& Sivasubramanaian, 2016). Further, Green HRM practices could also improve employees' 
workplace-related welfare (Renwick, Redman, \& Maguire, 2013; Macke \& Genari, 2018).

The impacts of Green HRM on individual outcomes could be grouped into green and non-green employee work outcomes (Shen, Dumont, \& Deng, 2018). The existing literature largely focused on the impacts of green HRM on green employees' outcomes, including green innovation (Alhadid \& Abu-Rumman, 2014), pro-environmental behavior, employee environment commitment, green recovery performance (Luu, 2018), green lifestyle (Ragas et al., 2017), green behavior and individual green value (Dumont, Shen, \& Deng, 2017), employee morale (Devi Kalpana, 2018), pro-environmental commitment (Sakka, 2018), as well as green passion and green creativity (Jia et al., 2018). However, a number of studies have also developed the impact of Green HRM on non-green employee work outcomes such as the sense of ownership and organization identity (Wulansari, Witiastuti, \& Ridloah, 2018), employee task performance, OCB, intention to quit (Shen, Dumont, \& Deng, 2018); job (Ragas et al., 2017); and employee loyalty (Devi Kalpana, 2018).

\section{Research method}

This paper relied on a qualitative exploratory approach in a multinational cement company in Indonesia that was renowned for its environmentally friendly reputation. The study obtained qualitative data from several key informants, as well as observations in the office and factory areas. The interview and observation data were also supplemented with secondary data of company documents related to the implementation of environmentally friendly activities, such as company regulations, standard operating procedures (SOPs), and company's sustainable development reports.

The research informants consisted of three company leaders, namely the Organization \& Human Resource Director (A1), the Corporate Environment \& Sustainable Development Manager (A2) and the Corporate Social Responsibility Manager (A3) and two employees (B1 and B2) as other informants. The interview process involved these company leaders because they were directly involved in implementing green business in the studied company. Specifically, they were the initiators and decision-makers, as well as the controllers of every company policy. Thus, they could be considered as those who understood and mastered well the implementation of Green HRM in the company, both strategically and operationally. Meanwhile, the study involved employees as the informants because they were also directly involved in the implementation of Green HRM in the company.

The data collection technique used triangulation principle where the data collection started with focus group discussions, followed by in-depth interviews with informants and supplemented by observation. The study also cross-checked the information from the interview with those from employees, customers, and suppliers. Further, the research also cross-checked the information through focus group discussion involving twenty-five employees who represented five departments of marketing, production, finance, HR, and CSR. Sutton and Austin (2015) emphasized that qualitative research did not attempt to generalize the findings to a wider population. Qualitative research aims to highlight individuals' feelings and thoughts to provide a basis for a future stand-alone qualitative study or to help researchers map out survey instruments that are useful for quantitative studies. As a qualitative exploratory study, this research focused on a single case of a company that had applied the Green Business concept in Indonesia. Thus, this study takes a case study approach to extend the empirical evidence of the application of Green HRM in an Asian country context.

Because this study used qualitative data analysis techniques, according to Miles and Huberman (1992), this study consisted of three stages, namely data reduction, data presentation, and conclusion drawing. The data reduction stage selected and reduced data and left only relevant data that was related to the study problems and purposes. Next, the study presented the data by classifying or grouping the structured data systematically, regularly, and meaningfully so that the data can be easily interpreted in accordance with the studies carried out, and the conclusions could finally be made.

\section{Results and discussion}

\subsection{The implementation of Green HRM in the company}

The company studied acknowledged that the application of Green HRM was inseparable from the concept of the big Green Business that the company embraced. As a Green Business, the formulation of the company's vision and mission reflected the green concept of the company's business as seen in the formulation of the company's mission related to environmentally friendly concepts, namely: 1) ensuring zero danger in every operational and business activity; and 2) creating the same values and sustainable solutions for stakeholders. To implement the company's environmentally oriented vision and mission, the company determined environmentally friendly values such as orientation towards customers, integrity, eco performance/results, sustainability, people openness, and inclusion. These environmentally friendly values would then become the guideline for implementing Green Business concepts in the company's various activities such as green production, Green HRM, eco office, and so on.

Regarding the application in HRM, the results showed that the company implemented environmentally friendly values in HRM in several functions namely recruitment, employee development and training, employee empowerment and involvement, performance evaluation and reward systems. In the recruitment and selection function, the company had implicitly included environmentallyfriendly values in the selection and interviewing process for prospective employees, thus prioritizing the suitability 
of the prospective employee's character with environmentally friendly company commitments. Therefore, environmentally friendly values such as customer orientation, integrity, eco performance orientation, sustainability, people openness, and inclusion were included in the interview content for new employees. This can be seen from Al's statement and also A3's who gave a similar result: “...when we conduct assessments and interviews, environmentally friendly values are used as a guide in the recruitment and selection, but we do not explicitly ask prospective employees about green, but we implicitly use the values to find out to which extent the prospective employees' character is compatible with the company's green values."

The findings showed that environmentally friendly commitment had been implicitly included in the process of recruiting and selecting new employees. In relation to the recruitment activities, the other component used was job descriptions. The company thought that it was not necessary to explicitly list environmentally friendly elements in the employee's job descriptions. They gave an explanation through informant A1 who stated that: "...we have not included environmentally-friendly values explicitly in the job description, but for us, if the employees already have the character that fit the company's green values, we believe that the prospective employees will be able to easily behave environmentally because ... in short, environmentally friendly behavior is individual values that must be shown in carrying out all work tasks in this company."

Furthermore, to motivate employees to exhibit environmentally friendly behavior, the company needed to offer training and development to improve employees' environmentally friendly competency. The employees were required to have sufficient knowledge and skills regarding environmentally friendly behavior. Without this competence, they could not be environmentally friendly (Daily, Bishop, \& Massoud, 2012; Renwick, Redman, \& Maguire, 2013; Opatha \& Arulrajah, 2014). In this respect, the company had conducted orientation activities for new employees to establish an environmentally friendly work culture, to form employee green competencies, and to create a commitment toward an environmentally friendly behavior. The company also organized training programs related to green competency in supporting the implementation of the employee's job.

The information can be seen from the informant Al's statement: "We conducted 2-weeks induction programs during the orientation periods for new employees. During these programs, besides discussing job descriptions, we talk about various important issues that shape corporate culture and values, including how to behave environmentally friendly..., we also encourage them to have green commitment. Also, we routinely hold training activities related to green competency for employees in their respective fields."

The statement was confirmed by informant B1, stating that: "During my work here, I have participated in employee training several times and one of the topics that is always given is how to make us behave greenly, the company always encourages employees to use the available resources in the company."

In addition to the training programs, as a part of a global company, the company also conducted employee development programs on a global scale. This information can be seen from the statement of the informant A1 who said that they also carried out cross-country employee development activities, considering they were a global company. They had sent employees to countries through employee exchange programs to make employees ed similar concepts and perceptions about Green Business globally.

To empower and involve employees in environmentally friendly activities, the company had provided the widest opportunity for all employees, both individually and in groups (trade unions) to be actively involved in forming environmentally friendly behavior in the company.

Employees were actively involved in both environmentally friendly office and factory activities. This explanation can be seen from informant A3 who stated that: "... in addition to have green solutions for our products, we have Eco-Office to reduce chemicals and paper usage and to save energy. As a Green Business, all our actions and activities in the company are directed towards integrated eco-green, and this can only be achieved if all employees are actively involved in it."

Informant A1 added the following information: "...we provide the widest opportunity for every employee to learn something from all the available functions. In our company, there is a culture that lets every employee have the initiative to submit ideas freely. Each leader provides an open space for ideas from employees. We have 2700 employees, and 9 division heads, so active employee involvement is needed."

Informant A3 responded to this statement by saying that: "...we have a Sustainable Development team that collaborates with Corporate Communication, and Communication Network members, in each office, each floor has a person in charge whose duty is to socialize, mobilize and remind environmentally friendly behavior. It aims to familiarize it so that every employee behaves environmentally friendly in the company environment."

The employee performance appraisal function also needed to support the implementation of Green HRM. For example, it was necessary to include environmentally friendly performance indicators in the performance appraisal, communicate environmentally friendly schemes to all levels of staff through performance appraisal schemes, make extensive dialogue on environmentally friendly behavior, set targets for managers/employees to behave environmentally friendly and evaluate employees' job performance in accordance with the environmentally friendly criteria (Renwick, Redman, \& Maguire, 2013; Opatha \& Arulrajah, 2014; Mehta \& Chugan, 2015).

Responding to this suggestion, informant A1 stated that: "Those who conduct performance appraisals are ecooffice teams that are directly responsible for this. The assessing team is associated with environmentally friendly behavior, for example, whether the plants on the table are 
well-maintained, the tables are cleaner and more practical, saving the use of paper, water, electricity and other materials."

The performance appraisal of the company had given a responsibility to the heads of each unit to assess and evaluate the implementation of environmentally friendly behavior for employees. The company also had global key performance indicators related to environmentally friendly concepts. What the company did was in line with previous studies that suggested that a performance appraisal process for environmentally friendly companies needed to determine environmental behavior indicator standards and included them in a comprehensive performance appraisal system (Opatha \& Arulrajah, 2014; Mehta \& Chugan, 2015).

To implement Green HRM for reward and punishment functions, the company must formulate and publish rules regarding environmentally friendly behavior. Also, the company could develop a disciplinary system progressively to sanction employees who violated the environmentally friendly rules and conversely reward employees who behaved environmentally-friendly (Phillips, 2007; Alhadid \& Abu-Rumman, 2014). In the company studied, there had been regulations that offer awards to encourage environmentally-friendly behavior. The company gave various awards - both explicit and implicit - to employees who had environmentally friendly behavior.

Concerning awards, informant A1 mentioned that: ".... We do not provide compensation directly related to environmentally friendly behavior. However, we give awards to employees for their environmentally friendly behavior. For example, in the eco-office programs; employees with the most tangible environmentally friendly behavior will receive prizes. For us, implementing Green Business enables us to enhance operational efficiency, and we can use the efficiency gains to increase employee well-being."

Furthermore, still in relation to giving awards and punishment, informant A3 revealed that: "...if the employee can make a green innovation, the employee will get a bonus or reward, and conversely if the employee does not innovate, he/she will get nothing."

The interview to a senior employee (B2) to confirm the previous statement revealed that: "... I have got more than what the company gives to me. We also never demand additional well-being to the company. For me, environmentally friendly behavior is something that I should have done without having to ask for compensation, although the company does provide several prizes every year for employees who are considered to have a good performance related to environmentally friendly behavior."

In addition to the above functions, the company had paid much attention to employee health and safety. In particular, the company used the green principles as the operating standards that facilitate employee health and safety. This description can be seen from informant A2 who explained that: "...we are a cement-producing company, where most of our employees work in factories and fields. We are responsible for employee health and safety, that's number one. Therefore, in terms of occupational health and safety, the company has used environmentally friendly principles applied in the occupational health and safety function for employees, contractors, local residents, and customers."

Next, informant A3 also added that: "Our company has a Corporate Safety Committee whose mission is to ensure that the application of $\mathrm{K} 3(\mathrm{OSH})$ standards meet national and international regulations. We also routinely hold $\mathrm{OSH}$ training in collaboration with the Institution of Occupational Safety and Health (IOSH) to ensure the quality standards for implementing OSH."

From the discussion above, the following table (Table 1) presents the summary of the application of Green HRM:

Table 1. The Forms of Green HRM implementation in the company studied (source: Primary data, 2018)

\begin{tabular}{|c|c|}
\hline $\begin{array}{l}\text { HRM } \\
\text { function }\end{array}$ & $\begin{array}{c}\text { The Form of Green HRM Implementation Based } \\
\text { on HRM function }\end{array}$ \\
\hline $\begin{array}{l}\text { Recruit- } \\
\text { ment \& } \\
\text { selection }\end{array}$ & $\begin{array}{l}\text { Incorporating environmentally-friendly values } \\
\text { derived from the company's vision and mission } \\
\text { in the recruitment and selection process of } \\
\text { prospective employees; prioritizing the suitability } \\
\text { of the environmentally friendly characters of } \\
\text { prospective employees with an environmentally } \\
\text { friendly company commitment }\end{array}$ \\
\hline $\begin{array}{l}\text { Training \& } \\
\text { Develop- } \\
\text { ment }\end{array}$ & $\begin{array}{l}\text { Organizing orientation activities to induce } \\
\text { environmentally friendly values and culture and } \\
\text { establishing an environmentally friendly work } \\
\text { culture. } \\
\text { Organizing routine training activities related to } \\
\text { environmentally friendly competence. } \\
\text { Carrying out employee development } \\
\text { internationally through the employee exchange } \\
\text { program to enable employees to have the same } \\
\text { perception of global Green Business. }\end{array}$ \\
\hline $\begin{array}{l}\text { Employee } \\
\text { Empower- } \\
\text { ment }\end{array}$ & $\begin{array}{l}\text { Providing the widest opportunity for all } \\
\text { employees, both individually and in groups, to } \\
\text { be actively involved in forming environmentally } \\
\text { friendly behavior in the company. } \\
\text { Having a structured organizational system to } \\
\text { involve all levels of employees in eco-office } \\
\text { programs in office buildings }\end{array}$ \\
\hline $\begin{array}{l}\text { Perfor- } \\
\text { mance } \\
\text { Assess- } \\
\text { ment }\end{array}$ & $\begin{array}{l}\text { Having standards for evaluating environmentally } \\
\text { friendly behavior through key performance } \\
\text { indicators (KPI). } \\
\text { Conducting integrated performance } \\
\text { assessments by including criteria for evaluating } \\
\text { environmentally friendly behavior. }\end{array}$ \\
\hline $\begin{array}{l}\text { Reward } \\
\text { and } \\
\text { Punish- } \\
\text { ment }\end{array}$ & $\begin{array}{l}\text { Establishing rules and award system policies for } \\
\text { employees who had environmentally friendly } \\
\text { behavior. The awards were intrinsically or } \\
\text { extrinsically given. }\end{array}$ \\
\hline $\begin{array}{l}\text { Occupa- } \\
\text { tional } \\
\text { Health and } \\
\text { Safety }\end{array}$ & $\begin{array}{l}\text { Paying full attention to occupational health } \\
\text { and safety through the Corporate Safety } \\
\text { Committee whose mission was to ensure } \\
\text { the implementation of OSH standards that } \\
\text { met national and international regulations } \\
\text { and eventually to ensure the safety of not } \\
\text { only employees but also customers and other } \\
\text { stakeholders. }\end{array}$ \\
\hline
\end{tabular}




\subsection{The benefits of implementing Green HRM in the company}

The focus group discussions (FGDs) and in-depth interviews with the key informants indicated some benefits or positive impacts of the application of Green HRM as summarized in the table below (Table 2).

The results above showed that the company enjoyed several benefits for both employees and the organization from being an environmentally friendly company that applied Green HRM. In particular, as displayed in Table 2, the benefits can be summarized as follows (Table 3): 1) employees had individual green value; 2) employees behaved environmentally friendly in carrying out their work duties; and 3) employees had a green competency in the sense that they had environmentally friendly knowledge and abilities that were good to apply in their jobs; and employees had a high commitment to environmentally friendly behavior. Also, the benefits were confirmed by the focus group discussion with twenty-five employee representing five departments of marketing, production, finance, HR, and CSR.

Table 2. The benefits of implementing Green HRM for employees

\begin{tabular}{|c|c|}
\hline $\begin{array}{l}\text { The benefit } \\
\text { of Green } \\
\text { HRM }\end{array}$ & Result \\
\hline $\begin{array}{l}\text { Individual } \\
\text { Green } \\
\text { Values }\end{array}$ & $\begin{array}{l}\text { Employees had good knowledge and } \\
\text { understanding of environmentally-friendly } \\
\text { values. The value of environmentally friendly } \\
\text { values become the value of individual } \\
\text { employee values. }\end{array}$ \\
\hline $\begin{array}{l}\text { Green Beha- } \\
\text { vior }\end{array}$ & $\begin{array}{l}\text { Employees always showed eco-friendly } \\
\text { behavior in carrying out their working } \\
\text { activities in the office and factory environment. }\end{array}$ \\
\hline $\begin{array}{l}\text { Green } \\
\text { Competency }\end{array}$ & $\begin{array}{l}\text { Employees had environmentally friendly ability } \\
\text { and skills to carry out various activities in the } \\
\text { company }\end{array}$ \\
\hline $\begin{array}{l}\text { Green } \\
\text { Commit- } \\
\text { ment }\end{array}$ & $\begin{array}{l}\text { Employees had a high level of responsibility } \\
\text { and commitment in implementing the Green } \\
\text { Business concept in the company }\end{array}$ \\
\hline $\begin{array}{l}\text { Company } \\
\text { Positive } \\
\text { Image }\end{array}$ & $\begin{array}{l}\text { Employees felt proud to be able to join } \\
\text { a company that was committed to the } \\
\text { environment. Employees were proud of the } \\
\text { company's reputation as a green company from } \\
\text { various parties. }\end{array}$ \\
\hline $\begin{array}{l}\text { Sense of } \\
\text { Ownership }\end{array}$ & $\begin{array}{l}\text { Employees felt proud because they could } \\
\text { work in a company that had received many } \\
\text { environmental awards. }\end{array}$ \\
\hline $\begin{array}{l}\text { Job Satis- } \\
\text { faction }\end{array}$ & $\begin{array}{l}\text { Employees feel satisfied when working at the } \\
\text { company }\end{array}$ \\
\hline Loyalty & $\begin{array}{l}\text { Employee turnover rate was low, [and] } \\
\text { employees were loyal to the company }\end{array}$ \\
\hline $\begin{array}{l}\text { Job Perfor- } \\
\text { mance }\end{array}$ & $\begin{array}{l}\text { Employees felt that they receive sufficient well- } \\
\text { being from the company. Consequently, they } \\
\text { never demanded increased compensation from } \\
\text { the company, although their job performance } \\
\text { had increased. }\end{array}$ \\
\hline Well-being & $\begin{array}{l}\text { Enhanced operational efficiency enabled the } \\
\text { company to increase employees' well-being. }\end{array}$ \\
\hline
\end{tabular}

Table 3. The Benefits of Implementing Green HRM Concept for Organization (source: Primary data, 2018)

\begin{tabular}{|c|c|}
\hline $\begin{array}{l}\text { The benefit } \\
\text { of Green } \\
\text { HRM }\end{array}$ & Result \\
\hline $\begin{array}{l}\text { Green Orga- } \\
\text { nization } \\
\text { Culture }\end{array}$ & $\begin{array}{l}\text { "It is not easy to apply the Green Business } \\
\text { concept in the company, but now we can feel } \\
\text { that Green's organizational culture is present in } \\
\text { our company." }\end{array}$ \\
\hline $\begin{array}{l}\text { Pro-Environ- } \\
\text { mental } \\
\text { Climate }\end{array}$ & $\begin{array}{l}\text { “.... An environmentally friendly } \\
\text { organizational culture then forms a pro- } \\
\text { environmental working climate in our } \\
\text { company ..." }\end{array}$ \\
\hline $\begin{array}{l}\text { Resource } \\
\text { Efficiency }\end{array}$ & $\begin{array}{l}\text { "The environmentally friendly work } \\
\text { atmosphere can be experienced in this } \\
\text { company both at the production sites and at } \\
\text { the office." }\end{array}$ \\
\hline \multirow[t]{2}{*}{$\begin{array}{l}\text { Cost Reduc- } \\
\text { tion }\end{array}$} & $\begin{array}{l}\text { "We have green solutions to handle the } \\
\text { production process. At the office, we also } \\
\text { reduce the use of chemicals, papers, and } \\
\text { energy. All businesses focus on eco-green." }\end{array}$ \\
\hline & $\begin{array}{l}\text { By applying the Green Business concept, all } \\
\text { activities run more efficiently, greener, and } \\
\text { faster. Overall, there are significant savings in } \\
\text { resource usage. }\end{array}$ \\
\hline \multirow[t]{2}{*}{$\begin{array}{l}\text { Company's } \\
\text { Positive } \\
\text { Image }\end{array}$} & $\begin{array}{l}\text { "The national and international awards as } \\
\text { recognition of the company's performance are } \\
\text { undeniable, and the awards arguably improve } \\
\text { our company's image." }\end{array}$ \\
\hline & $\begin{array}{l}\text { "We are proud to work in a company that has } \\
\text { a good reputation." }\end{array}$ \\
\hline \multirow{2}{*}{$\begin{array}{l}\text { Economic \& } \\
\text { Environment } \\
\text { Performance }\end{array}$} & $\begin{array}{l}\text { "The company's performance increases after } \\
\text { we carry out Green Business extensively in our } \\
\text { company. I am sure it has something to do with } \\
\text { various efficiencies due to the implementation of } \\
\text { environmentally friendly activities." }\end{array}$ \\
\hline & $\begin{array}{l}\text { "The company's performance increases both } \\
\text { economically and environmentally as we } \\
\text { have received various awards, such as the } \\
\text { sustainable business award,.." }\end{array}$ \\
\hline \multirow{2}{*}{$\begin{array}{l}\text { Competitive } \\
\text { Advantage } \\
\text { \& Sustain- } \\
\text { ability }\end{array}$} & $\begin{array}{l}\text { "By implementing the Green Business concept } \\
\text { that we have taken seriously, it becomes our } \\
\text { work culture, [and] we feel that it can be one } \\
\text { of our competitive advantages in the industry } \\
\text { where we are currently engaged." }\end{array}$ \\
\hline & $\begin{array}{l}\text { "We are concerned about the sustainability of } \\
\text { our business in the long term, so we apply the } \\
\text { Green Business concept ..." }\end{array}$ \\
\hline
\end{tabular}

The implementation of the Green HRM concept can affected green competency and commitment. It can uderstable that competence was a part of individuals' inherent personality that can predict one's behavior in various task and work situations. The findings support a number of previous studies (Garavan et al., 2010; Sudin, 2011; Zoogah, 2011; Renwick, Redman, \& Maguire, 2013; Gotschol, De Giovanni, \& Vinzi, 2014; Macke \& Genari, 2018) that demonstrated that the implementation of the Green HRM concept led to increased employees' competence and commitment to environmentally friendly behavior. 
In Addition, the application of Green HRM would affect individuals or employees by increasing a sense of pride and belonging towards the company, enhancing, increasing job satisfaction and loyalty, improving employee well-being, and increasing job performance. In particular, employees felt proud to be able to join a company that was committed to the environment and received many environmental awards. This pride could further encourage employees to be more satisfied and loyal to the company (Wulansari, Witiastuti, \& Ridloah 2018). Further, Renwick, Redman, and Maguire (2013), Macke and Genari (2018) argued that Green HRM likely improved performance, employee well-being, and employee satisfaction. Also, Cherian and Jacob (2012) revealed that one of the effects of implementing environmentally-friendly behavior was increased employee loyalty due to high employee job satisfaction.

At the organizational level, this study several benefits from implementing environmentally friendly business and Green HRM. First, the implementation led to the formation of environmentally friendly culture and environmentally friendly work climate in the company. Next, it caused the efficient use of resources and the reduction of operational costs for various activities in the company. The company's decision to implement the green solution movement that focused on eco-green could enhance the efficiency of resource use, which in turn reduced the company's operating costs. The ecofriendly concept required the efficient use of various resources to reduce waste of resources (Shaikh, 2010; Alhadid \& Abu-Rumman, 2014) and to generate budget savings (Ekasatya, 2014).
Furthermore, implementing an environmentally friendly concept also benefitted the company by enhancing the company's image in the eyes of their employees and the wider community. The company's various efforts and initiatives to implement the Green Business concept made the company receive various awards from numerous parties, both national and international ones. The awards would arguably enhance the company's reputation both at national and international levels.

Finally, the application of Green HRM would improve organizations' economic and environmental performance and competitive advantage that would eventually help the company achieve organizational sustainability. In this respect, Leonidou et al. (2017) concluded that well-run Green Business strategies helped companies achieve significant competitive advantages, which in turn would improve business performance.

\section{Discussion}

This study investigated the implementation of Green HRM in a company that applied environmentally friendly concepts. It described the implementation of Green Business implementation within the HRM functions and identified the benefits of the implementation of Green HRM for employees and organization (Mehta \& Chugan, 2015; Rawashdeh, 2018; Obaid \& Rosima, 2015; Sayyadi Tooranloo, Azadi, \& Sayyahpoor, 2017; Wu et al., 2019). Figure 1 below illustrates the summary of the results:

This study found that the application of Green HRM would only succeed in companies that were committed to implementing Green Business concepts. In line with

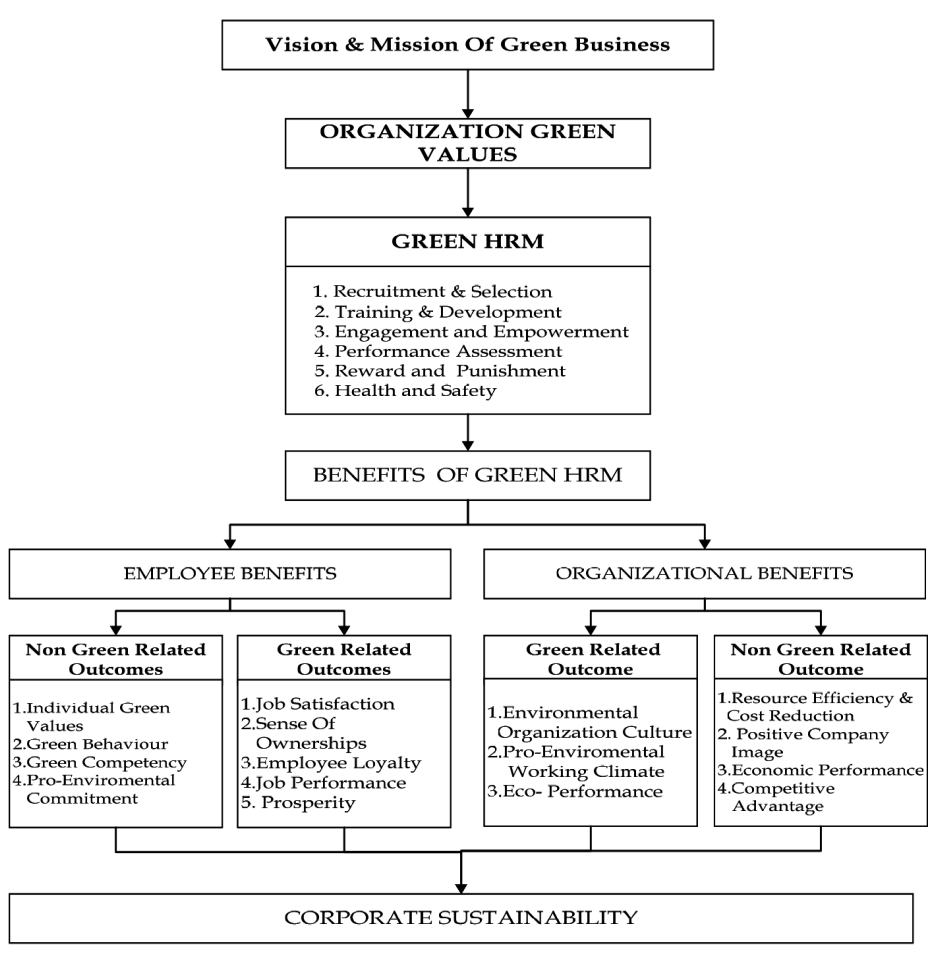

Figure 1 . The modeled summary of the results 
the stakeholder theory, the company's green commitment emerged due to the demands of the stakeholders and the company's awareness of the importance of sustainable performance that balanced the economic and environmental performance (Renwick, Redman, \& Maguire, 2008; Jackson et al., 2011; Siyambalapitiya, Zhang, \& Liu, 2018; Macke \& Genari 2018; Sayyadi Tooranloo, Azadi, \& Sayyahpoor, 2017; Wu et al., 2019). As a cement-producing company with potential environmental impacts, the studied company had moral and ethical responsibilities to reduce its environmental impacts by committing to implement the Green Business concept.

The company then integrated the Green Business concept into its vision and mission and developed several green values as the basis to establish environmentally friendly policies and practices within all company's activities, such as green production, Green HRM, Eco-office, and so on. The study also found that the application of Green HRM aimed to establish a Green behavior and culture for all employees.

The company implemented the Green HRM concepts in various HRM functions, including recruitment \& selection, employee development and training, employee empowerment and involvement, performance assessment, reward systems, and occupational safety and health. These findings were in line with previous studies. For example, during the recruitment and selection activities, the company included environmentally-friendly criteria in recruitment materials, communicated environmentally-friendly commitments to applicants and prioritized applicants who had experience in environmentally friendly activities (Renwick, Redman, \& Maguire, 2013; Opatha \& Arulrajah, 2014).

In the employee training and development, the company had conducted the orientation activities for new employees to shape company's culture and values by emphasizing environmentally friendly work culture, work safety, and commitment to environmentally friendly behavior. The results also showed that the company conducted the training and development activities smoothly by providing extensive opportunities for all employees to innovate within the company's environmentally friendly values. As suggested by previous studies (Renwick, Redman, \& Maguire, 2013; Opatha \& Arulrajah, 2014), companies needed to include environmentally friendly values in the employee training and development function, both formally and informally.

For the implementation of Green HRM in other HRM functions, the company made green values as the basis for implementing activities. For example, for the performance appraisal or performance management activities, the company used environmentally friendly concepts as the KPI parameters in performance appraisal. This action was similar to Opatha and Arulrajah (2014), Mehta and Chugan (2015) who argued that in Green HRM, environmentally friendly behavior must be the part of the employee performance appraisal system. Next, the company applied environmentally friendly behavior in the reward and punishment practice by focusing more on rewards than punishment. Specifically, the company provided awards for employees who showed outstanding environmentally friendly performance. It was expected that the awards would motivate employees to be environmentally friendly. Thus, the company believed that positive reinforcement was more effective than negative reinforcement in encouraging environmentally-friendly behavior.

Other findings that were worth discussing were related to the identification of benefits or the positive impacts of the application of Green HRM. The exploratory results showed that the application of Green HRM in organizations provided positive benefits for individual employees and the organizations. At the individual level, the implementation of Green HRM affected employees' green work outcomes, such as increased green values, green behavior, green competencies, and green commitment or pro-environmental commitment. The basic green values introduced by the company since the first day of the employees had been internalized into individual green values (Dumont, Shen, \& Deng, 2017) and were manifested by green behavior (Luu, 2018) and green competencies and proenvironmental commitment (Sakka, 2018) in employees' activities (Cherian \& Jacob, 2012; Gotschol, De Giovanni, \& Vinzi, 2014). The results are also in line with Dumont, Shen, and Deng (2017) who proposed that Green HRM affected employees' environmentally friendly behavior both directly and indirectly.

Also, the application of the Green HRM concept positively affected employees' non-green work outcomes, comprising of job satisfaction, employee loyalty, sense of belonging and pride in the company, job performance, and increased employees' well-being. These findings support several previous studies, including job satisfaction (Cherian \& Jacob, 2012; Renwick, Redman, \& Maguire, 2013), employee loyalty/decreasing turnover (Shen, Dumont, \& Deng, 2018; Devi Kalpana, 2018), sense of belonging (Wulansari, Witiastuti, \& Ridloah, 2018), job performance (Ragas et al., 2017), and employees' well-being (Renwick, Redman, \& Maguire, 2013).

The company itself recognized the organizational benefits of the application of Green Business. For example, the implementation created an environmentally friendly organizational culture and work climate. Additionally, the company could increase the efficiency of the use of various resources (energy, water, electricity, paper, raw materials, and other materials) and reduce unnecessary waste or costs in various activities. Also, the implementation of Green HRM enhanced corporate image or reputation in the eyes of internal and external stakeholders, which in turn likely generated trust to the company. Eventually, the most important benefits of applying the Green Business concept was improved economic and environmental performance at the organizational level.

The results confirmed previous studies such as Renwick, Redman, and Maguire (2013), Gotschol, De Giovanni, and 
Vinzi (2014), Alhadid and Abu-Rumman (2014), Opatha and Arulrajah (2014). Alwhich argued that implementing environmentally friendly practices in organizations would arguably improve organizational performance, such as increasing the efficiency of resource use (Shaikh, 2010); cutting unnecessary costs (Ekasatya, 2014; Haridas \& Sivasubramanaian, 2016); improving corporate image as a friendly organization environment (Cherian \& Jacob, 2012; Haridas \& Sivasubramanaian, 2016; Devi Kalpana, 2018); improving economic and environmental performance or, as labeled by Obaid and Rosima (2015), achieving a sustainable organization's environmental performance.

The studied company believed that the consistent and integrated application of the Green Business and Green HRM concepts would ultimately enable the company to have a competitive advantage (Aykan, 2017; Leonidou et al., 2017). The belief was in line with the resource-based view theory that proposes that organizations must rely on internal resources that are valuable, rare, difficult to replicate, and well-organized to achieve sustainable competitive advantage. In this respect, the application of structured eco-friendly concepts could be a source of competitiveness for the company to ensure corporate sustainability (Mehta \& Chugan, 2015; Obaid \& Rosima, 2015; Lazăr, 2017; Rawashdeh, 2018). Thus, the study adds the existing literature that supports the importance of Green HRM practices because of numerous benefits for companies.

Further, the results showed that Green HRM practices are very crucial to create environmentally friendly behavior for employees and organizations and to help materialize numerous benefits of Green HRM to companies and employees. The findings also underscore that the presence of environmentally friendly innovations will enhance organizational performance. Thus, the results highlight that companies that implement environmentally friendly management practices will enjoy benefits at the national and international levels by achieving significant savings from the use of organizational resources.

\section{Conclusions}

The application of Green HRM requires full commitment to implement the Green Business concept. Companies implement Green HRM to establish Green behavior culture for all employees by internalizing green values in the overall function of HRM functions that consist of recruitment and selection activities, employee development and training, employee empowerment and involvement, performance appraisal, reward system, and occupational safety and health.

The application of Green HRM in organizations provides benefits for individual employees and the organization. At the individual level, the benefits manifest in green work outcomes such as increasing green individual values, green behavior, green competencies and pro-environmental commitment; and non-green work outcomes such as job satisfaction, employee loyalty, sense of ownership, job performance and increased employee well-being.
At the organizational level, the application of Green Business and Green HRM offers various benefits, such as the creating environmentally friendly organizational culture and work climate, increasing the efficiency of various resources, reducing unnecessary waste of money, establishing a positive image of the company and increasing organizations' economic performance and performance environment or eco-performance. The findings confirm previous studies.

\section{Limitations and future research recommendations}

This research is a qualitative exploratory study in a single company that has applied the Green Business concept in Indonesia. Although the results clearly illustrate the application of Green HRM and its benefits, these findings cannot be generalized for other Indonesian companies. Thus, the study recommends future studies to investigate the same topic in more environmentally friendly companies, thus potentially resulting in richer and diverse analysis.

Also, this study only focuses on the application of Green HRM and its impacts. The findings suggest that the studied company did not immediately implement Green HRM. Instead, the company needed to undergo a series of the process, starting from internalizing green values into its vision and mission and followed by implementing various policies and practices. This paper advises future studies to examine how the process of internalizing the Green Business values results in environmentally friendly behavior for employees and organizations. Besides contributing to the Green Business literature, such studies will inform companies that are interested in applying the Green Business concepts.

This study proposes a model that illustrates the various benefits of applying Green HRM for employees and companies. This model needs to be tested through explanatory research that is a research opportunity for future Green HRM studies. Meanwhile, this study and most of the Green HRM literature largely focus on the impacts of the application of Green HRM. It is suggested that future research also investigates the determinants or external factors that motivate companies to implement Green HRM. A factor that is worth analyzing is local culture that likely plays an important role in explaining diverse Green HRM practices in different countries. Thus, the literature will provide a more comprehensive understanding of the Green HRM practices in organizations.

\section{References}

Aguinis, H., \& Glavas, A. (2012). What we know and don't know about corporate social responsibility: a review and research agenda. Journal of Management, 38(4), 932-968. https://doi.org/10.1177/0149206311436079

Alhadid, A. Y., \& A. H. Abu-Rumman. (2014). The impact of green innovation on organizational performance, environmental management behavior as a moderate variable: an ana- 
lytical study on nuqul group in Jordan. International Journal of Business and Management, 9(7), 51-58.

https://doi.org/10.5539/ijbm.v9n7p51

Aykan, E. (2017). Gaining a competitive advantage through green human resource management. In Corporate governance and strategic decision making. IntechOpen.

https://doi.org/10.5772/intechopen.69703

Bissing-Olson, M. J., Iyer, A., Fielding, K. S., Zacher, H. (2013). Relationships between daily affect and pro-environmental behavior at work: the moderating role of pro-environmental attitude. Journal of Organizational Behavior, 34(2), 156-175. https://doi.org/10.1002/job.1788

Čekanavičius, L., Bazyte, R., \& Dičmonaite, A. (2014). Green business: challenges and practices. Ekonomika, 93, 74-88. https://doi.org/10.15388/Ekon.2014.0.3021

Chams, N., \& García-Blandón, J. (2019). On the importance of sustainable human resource management for the adoption of sustainable development goals. Resources, Conservation, and Recycling, 141 (February), 109-122.

https://doi.org/10.1016/j.resconrec.2018.10.006

Cherian, J. P., \& Jacob, J. (2012). A Study of Green HR practices and its effective implementation in the organization: a review. International Journal of Business and Management, 7(21), 1-15. https://doi.org/10.5539/ijbm.v7n21p25

Daily, B. F., Bishop, J. W., \& Massoud, J. A. (2012). The role of training and empowerment in environmental performance: a study of the Mexican Maquiladora industry. International Journal of Operations \& Production Management, 32(5), 631647. https://doi.org/10.1108/01443571211226524

Devi Kalpana, J. K. (2018). Influence of Green HRM practices on employees performance level - a study with reference to literature review. International Journal of Research and Analytical Reviews (IJRAR), 5(3), 329-333.

Dumont, J., Shen, J., \& Deng, X. (2017). Effects of Green HRM practices on employee workplace Green behavior: the role of psychological green climate and employee green values. $\mathrm{Hu}$ man Resource Management, 56(4), 613-627. https://doi.org/10.1002/hrm.21792

Ekasatya, H. N. (2014). Penerapan Kesadaran Lingkungan Dengan Penghematan Anggaran Listrik, Kertas, Air Di Kantor Badan Lingkungan Hidup Kabupaten Probolinggo. Calyptra, $3(2), 1-15$.

Florida, R., \& Davison, D. (2001). Gaining from green management: environmental management systems inside and outside the factory. California Management Review, 43(3), 64-84. https://doi.org/10.2307/41166089

Garavan, T. N., Heraty, N., Rock, A., \& Dalton, E. (2010). Conceptualizing the behavioral barriers to CSR and CS in organizations: a typology of HRD interventions. Advances in Developing Human Resources, 12(5), 587-613.

https://doi.org/10.1177/1523422310394779

Gotschol, A., Giovanni, P. De, \& Vinzi, V. E. (2014). Is environmental management an economically sustainable business? Journal of Environmental Management, 144, 73-82. https://doi.org/10.1016/j.jenvman.2014.05.001

Haridas, P. K., \& Sivasubramanaian, Ch. (2016). Impact of Green HRM Practices on company performance: with special reference to manufacturing industry. International Journal of Engineering Technology Science and Research, 3(12), 49-54.

Jabbour, Ch. J. Ch., \& de Sousa Jabbour, A. B. L. (2016). Green Human resource management and Green Supply chain management: linking two emerging agendas. Journal of Cleaner Production, 112 (January), 1824-1833. https://doi.org/10.1016/j.jclepro.2015.01.052
Jackson, S. E., Renwick, D. W. S., Jabbour, Ch. J. C., \& MullerCamen, M. (2011). State-of-the-Art and future directions for green human resource management: introduction to the special issue. German Journal of Human Resource Management, 25(2), 99-116. https://doi.org/10.1177/239700221102500203

Jia, J., Liu, H., Chin, T., \& Hu, D. (2018). The continuous mediating effects of GHRM on employees' Green passion via transformational leadership and green creativity. Sustainability, 10(9), 3237. https://doi.org/10.3390/su10093237

Kitazawa, S., \& Sarkis, J. (2000). The relationship between ISO 14001 and continuous source reduction programs. International Journal of Operations \& Production Management, 20(2), 225-248. https://doi.org/10.1108/01443570010304279

Lazăr, C. I. (2017). Perspectives on Green marketing and green businesses for sustainable development. Bulletin of the Transilvania University of Brasov. Economic Sciences. Series V, 10(1), 45-52.

Leonidou, L. C., Christodoulides, P., Kyrgidou, L. P., \& Palihawadana, D. (2017). Internal drivers and performance consequences of small company Green business strategy: the moderating role of external forces. Journal of Business Ethics, 140(3), 585-606. https://doi.org/10.1007/s10551-015-2670-9

Luu, T. T. (2018). Employees' Green Recovery performance: the roles of Green HR practices and serving culture. Journal of Sustainable Tourism, 26(8), 1308-1324.

https://doi.org/10.1080/09669582.2018.1443113

Macke, J., \& Genari, D. (2018). Systematic literature review on sustainable human resource management. Journal of Cleaner Production, 208(January), 806-15. https://doi.org/10.1016/j.jclepro.2018.10.091

Mehta, K., \& Pawan K. Ch. (2015). Green HRM in pursuit of environmentally sustainable business. Universal Journal of Industrial and Business Management, 3(3), 74-81.

Miles, M. B., \& Huberman, A. M. (1992). Analisis Data Kualitatif. Jakarta: UI Press.

Obaid, T. F., \& Rosima, B. (2015). The impact of Green recruitment, Green training, and Green learning on the company performance: conceptual paper. International Journal of Applied Research, 1(12), 951-953.

Opatha, H. H. D. N. P., \& Arulrajah, A. A. (2014). Green human resource management: simplified general reflections. International Business Research, 7(8). https://doi.org/10.5539/ibr.v7n8p101

Paillé, P., Chen, Y., Boiral, O., \& Jin, J. 2014. The impact of human resource management on environmental performance: an employee-level study. Journal of Business Ethics, 121(3), 451-466. https://doi.org/10.1007/s10551-013-1732-0

Pfeffer, J. (2010). Building sustainable organizations: the human factor. Academy of Management Perspectives, 13. https://doi.org/10.2139/ssrn.1545977

Phillips, L. (2007). Go Green to gain the edge over rivals. People Management, 23(9).

Ragas, S. F. P., Tantay, F. M. A., Chua, L. J. C., \& Sunio, C. M. C. (2017). Green lifestyle moderates GHRM's impact on job performance. International Journal of Productivity and Performance Management, 66 (7), 857-872. https://doi.org/10.1108/IJPPM-04-2016-0076

Ramus, C. A., \& Steger, U. (2000). The roles of supervisory support behaviors and environmental policy in employee "ecoinitiatives" at leading-edge European companies. Academy of Management Journal, 43(4), 605-626. https://doi.org/10.2307/1556357

Rani, S., \& Mishra, K. (2014). Green HRM: practices and strategic implementation in the organizations. International Journal 
on Recent and Innovation Trends in Computing and Communication, 2(11), 3633-3639.

https://doi.org/10.2224/sbp.2013.41.7.1083

Rawashdeh, A. (2018). The Impact of green human resource management on organizational environmental performance in jordanian health service organizations. Management Science Letters, 8(10), 1049-1058. https://doi.org/10.5267/j.msl.2018.7.006

Renwick, D., Redman, T., \& Maguire, S. (2008). Green HRM: a review, process model, and research agenda. University of Sheffield Management School Discussion Paper, 2008(1), 1-46. https://doi.org/10.1111/j.1468-2370.2011.00328.x

Renwick, D. W. S., Redman, T., \& Maguire, S. (2013). Green human resource management: a review and research agenda*: Green human resource management. International Journal of Management Reviews, 15(1), 1-14. https://doi.org/10.1111/j.1468-2370.2011.00328.x.

Sakka, Sh. E. (2018). Impact of Green human resource management (Ghrm) practices on enhancing supply chain image and performance. Global Journal of Human Resource Management, 6(3), 70-78.

Sayyadi Tooranloo, H., Azadi, M. H., \& Sayyahpoor, A. (2017). Analyzing factors affecting implementation success of sustainable human resource management (SHRM) using a Hybrid Approach of FAHP and Type-2 Fuzzy DEMATEL. Journal of Cleaner Production, 162(September), 1252-1265. https://doi.org/10.1016/j.jclepro.2017.06.109

Shaikh, M. W. (2010). Green HRM, a requirement of 21 st century. Journal of Research in Commerce and Management, 1, $122-127$

Shen, J., Dumont, J., \& Deng, X. (2018). Employees' perceptions of green HRM and non-green employee work outcomes: the social identity and stakeholder perspectives. Group \& Organization Management, 43(4), 594-622. https://doi.org/10.1177/1059601116664610

Siyambalapitiya, J., Zhang, X., \& Liu, X. (2018). Green human resource management: a proposed model in the context of
Sri Lanka's tourism industry. Journal of Cleaner Production, 201(November), 542-555.

https://doi.org/10.1016/j.jclepro.2018.07.305

Soo Wee, Y., \& Quazi, H. A. (2005). Development and validation of critical factors of environmental management. Industrial Management \& Data Systems, 105(1), 96-114. https://doi.org/10.1108/02635570510575216

Sudin, S. (2011). Strategic Green HRM: A proposed model that supports corporate environmental citizenship. In International Conference on Sociality and Economics Development, IPEDR, 10, 79-83. http://www.ipedr.com/vol10/16-E10014.pdf

Sutton, J., \& Austin, Z. (2015). Qualitative research: data collection, analysis, and management. The Canadian Journal of Hospital Pharmacy, 68(3). https://doi.org/10.4212/cjhp.v68i3.1456

Wagner, M. (2013). Green' Human resource benefits: do they matter as determinants of environmental management system implementation? Journal of Business Ethics, 114(3), 443-456. https://doi.org/10.1007/s10551-012-1356-9

Wu, K.-J., Tseng, M. L., Lim, M. K., \& Chiu, A. S. F. (2019). Causal sustainable resource management model using a hierarchical structure and linguistic preferences. Journal of Cleaner Production, 229 (August), 640-651. https://doi.org/10.1016/j.jclepro.2019.04.394

Wulansari, N. A., Witiastuti, R. S., \& Ridloah, S. (2018). Employee performance measurement development based on Green HRM indicators. KnE Social Sciences, 3(10), 1179-1194. https://doi.org/10.18502/kss.v3i10.3201

Yong, J. Y., Yusliza, M.-Y., Ramayah, T., \& Fawehinmi, O. (2019). Nexus between green intellectual capital and green human resource management. Journal of Cleaner Production, 215(April), 364-374. https://doi.org/10.1016/j.jclepro.2018.12.306

Zoogah, D. B. (2011). The dynamics of green HRM behaviors: a cognitive social information processing approach. German Journal of Human Resource Management, 25(2), 117-139. https://doi.org/10.1177/239700221102500204 